\title{
WAB-450: A valuable donor of earliness and productivity traits for rice breeding programme under rainfed upland ecosystem
}

\author{
Sangodele Emmanuel A. ${ }^{1 \star}$, Hanchinal R. R. ${ }^{1}$, Hanamaratti N. G. ${ }^{1}$, Vinay Shenoy ${ }^{2}$, Nadaf H. L. \\ and Mohan Kumar V. ${ }^{2}$
}

${ }^{1}$ Department of Genetics and Plant Breeding, University of Agricultural Sciences, Dharwad, Karnataka State, India.
2Barwale Foundation, Hyderabad, AP, India

Accepted 25 March, 2013

\begin{abstract}
This study focused on evaluation of introgressed population for earliness in flowering and productivity under rainfed upland rice ecosystem. The population was derived from inter-varietal cross between early maturing Africa upland land rice WAB-450, an inter-specific derivative as donor and Swarna, a mega rice variety from India, as recurrent parent. One hundred and eighty eight (188) backcross inbred lines (BILs) with the two parents were evaluated during kharif 2011 at Mugad Agricultural Research Station (ARS), University of Agricultural Sciences Dharwad. The BILs showed significant improvement over Swarna for earliness in flowering and productivity under natural rainfed condition. The frequency distribution of days to $50 \%$ flowering observed in this study showed continuous variation. The distribution was normal indicating inheritance of a quantitative trait and influence of WAB-450 genome contribution in one backcross in the expression of this trait. The BILs which flower between 90 and 100 days and mature around $\mathbf{1 2 0}$ to 135 days with high yield coupled with other desired traits such as grain quality have been identified for upland rice ecosystem.
\end{abstract}

Key words: Backcross inbred lines, $W A B-450$, population, flowering.

\section{INTRODUCTION}

Rice has a series of species and wild relatives that can be used to address specific breeding problems such as tolerance to biotic and abiotic stresses. However, one of the main limitations on the use of wild relatives in breeding programs is the lack of cross-ability between species due to chromosomal and genetic differences. One alternative to overcome these sexual barriers is to use embryo rescue and protoplast fusion, which are simple biotechnology techniques that have been used successfully in rice. Fertile cultivated rice Oryza sativa and Oryza glaberrima progenies were obtained through backcrossing and double haploid production by Jones et al. (1997). The NERICA varieties provide a good example of how these techniques were used to help address some specific breeding objectives.

Long before Asian rice ( $O$. sativa) reached Africa's shores, local farmers had domesticated a local species to develop African cultivated rice ( $O$. glaberrima). The domestication of $O$. glaberrima took place 3,500 years ago (Porteres, 1955). Thus, its local ancestry and numerous generations of selection in situ have made $O$. glaberrima well adapted to the African environment. On the other hand, $O$. sativa especially the Green Revolution semi dwarf varieties has been bred for intensive production 
and high yield, but outside of the African continent. The first Asian varieties arrived in Africa about 450 years ago, and they have subsequently replaced the local species in much of the rice-cultivated area (WARDA, 2001).

The Africa cultivated rice ( $O$. glaberrima) is adapted to the African environment, but prone to lodging and grain shattering (Koffi, 1980; Jones et al., 1997; Dingkuhn et al., 1998). The Asian cultivated rice (O.sativa) is high yielding, but susceptible to the stresses of African ecologies (WARDA, 2001). Rice breeders had long since dreamed of combining the best traits of the two species, but previous attempts had failed, as the resulting offspring were all sterile. In the early 1990s, WARDA breeders turned to biotechnology in an attempt to overcome the infertility problem. The breakthrough came from embryo-rescue technique and anther culture; a new plant type was developed from almost sterile resultant plant by several backcrosses with the sativa parent. Embryo rescue technique was employed to obtain viable segregating populations (Jones et al., 1997). Since then, the techniques have been refined and streamlined, so that many new lines are generated each year; for example $W A B-450$ progeny was developed from crosses of the existing released variety CG 14 (O. glaberrima Steud.) and WAB56-104, which belong to the subspecies japonica of $O$. sativa $L$., an upland improved variety (Somado et al., 2008).

Major advantageous traits from glaberrima that occur in some progenies of the new plant type are: early maturity, drought tolerance, resistance to diseases especially African rice gall midge, rice yellow mottle virus and blast disease. Other desirable characters include good taste, aroma and other grain qualities favored by farmers. Meanwhile, the sativa parents have also given their best to the WAB-450: non-shattering grains, good tillering and high yielding. $W A B-450$ has a yield advantage over their $O$. glaberrima and $O$. sativa parents, and superior in earliness, weed competitiveness, drought tolerance, and pest or disease resistance (Africa Rice, 2011). The introgression of WAB-450 genome in elite background could impart earliness, stress tolerance and productivity related traits thus the present investigation was undertaken to identify the introgression line with early maturity and higher yield suitable to rainfed upland condition.

\section{MATERIALS AND METHODS}

The investigation was carried out under natural rain situation at Agricultural Research Station (ARS) Mugad, University of Agricultural Sciences Dharwad, India. The Research Station is located at latitude of $15^{\circ} 15^{\prime}$ North and longitude of $70^{\circ} 40^{\prime}$ East and altitude of $695 \mathrm{~m}$ above mean sea level (MSL) belonging to Agroclimatic zone No. 8 of Karnataka State. The average rainfall of the Research Station is $1016.20 \mathrm{~mm}$ in 75 rainy days distributed mainly during kharif (June to October) season. Breeding material for this study is backcross population $\left(\mathrm{BC}_{1} \mathrm{~F}_{6}\right)$ developed in India by Barwale Foundation in Hyderabad using WAB-450, an inter-specific derivative as donor and Swarna, a mega rice variety in India, as recurrent parent. The population $\left(188 \mathrm{BC}_{1} \mathrm{~F}_{6}\right.$ lines) along with the two parents (Swarna and WAB-450) were evaluated under natural rainfed ecosystem for flowering duration and productivity in randomized block designs during Kharif 2011. Recommended agronomic practices were dully followed for raising a good and healthy crop using Package of practices for Paddy developed by University of Agricultural Sciences, Dharwad (UAS Dharwad, 2009). Data was taken and analyzed using simple analysis of variance (ANOVA) to determine the mean performance of the backcross inbred lines (BILs) and parents for days to $50 \%$ flowering and productivity traits.

\section{RESULTS AND DISCUSSION}

The ANOVA in respect of all the characters studied in BILs derived from a cross between Swarna $\times$ WAB-450 indicate highly significant genotypes' mean sum of square (GMSS) for genotypes indicating wide genetic differences for all productivity traits studied besides days to $50 \%$ flowering and maturity (Table 1 ). Heritability $\left(h^{2}\right)$ of traits like days to $50 \%$ flowering, days to maturity, plant height, productive tillers and spikelet fertility are higher, while it is moderate for other traits like grain yield, grain weight and harvest index (Table 1). Whereas heritability measure the portion of parent that is passed on to the progeny genetic advance (GA) is the amount of genetic gain resulting from the crossing of the two parents; the two genetic parameters ( $h^{2}$ and $\left.G A\right)$ are useful indices of selection for desirable traits: the higher the heritability and GA of traits, the more effective the direct selection for that trait. The mean of BILs for days to $50 \%$ flowering, maturity as well as important productivity traits was intermediate, while the frequency distribution is normal distribution for days to $50 \%$ flowering. This may be due to higher dose of $W A B-450$ genome resulting from one backcross.

The frequency distribution of days to $50 \%$ flowering in BILs shows a continuous distribution curve of a quantitative trait with a clear divergence between the two parents $W A B-450$ and Swarna. In this study, 50\% flowering of $W A B-450$ was 82.5 days, while that of Swarna was 112 days. Days to $50 \%$ flowering data for the 188 BILs range between 82.5 and 125 (Figure 1). The mode of BILs distribution for this trait was a normal distribution; this suggest a possible conclusion that days to $50 \%$ flowering is under the control of relatively large number of genetic factors, each having relatively small effect. The range of BILs variation was apparently wider than the parental difference in the $\mathrm{BC}_{1} \mathrm{~F}_{6}$ populations; similarly, the difference between BILs means and the parental means is significant. According to Swain et al. (2010), Swarna is a long duration lowland rice variety which matures in 150 days. WAB-450 on the other hand is short duration varieties that mature between 95 to 100 days in tropical Africa upland ecosystem (Africa Rice, 2011). BILs developed from these two parents are expected to express a great deal of variability 
Table 1. ANOVA for earliness in flowering and productivity related traits.

\begin{tabular}{lcccc}
\hline Trait & Genotype MSS & Error MSS & $\mathbf{h}^{\mathbf{2}}$ & $\mathbf{G A}$ \\
\hline Days to 50\% flowering & $101.109^{\star *}$ & 13.9 & 75.9 & 11.4 \\
Days to maturity & $136.635^{\star *}$ & 12.8 & 82.1 & 11.0 \\
Plant height (cm) & $97.81^{\star *}$ & 10.1 & 81.2 & 15.0 \\
Number of tillers & $9.04405^{\star *}$ & 1.2 & 76.9 & 29.0 \\
Number of productive tillers & $7.01845^{\star \star}$ & 1.3 & 69.2 & 25.0 \\
Panicle length (cm) & $5.71549^{\star *}$ & 1.3 & 63.5 & 11.8 \\
Panicle weight (g) & $0.770921^{\star *}$ & 0.2 & 53.6 & 25.8 \\
grain number per panicle & $1381.07^{\star *}$ & 527.7 & 44.7 & 21.5 \\
Grain weight per panicle & $0.545154^{\star *}$ & 0.2 & 52.3 & 22.3 \\
Spikelet fertility (\%) & $169.602^{* *}$ & 24.7 & 74.6 & 18.0 \\
Yield per plant & $245.733^{* *}$ & 52.8 & 64.6 & 43.0 \\
Harvest index & $32.2568^{* *}$ & 10.7 & 50.3 & 11.9 \\
\hline
\end{tabular}

${ }^{* *}$, Significant at 0.01 probability.

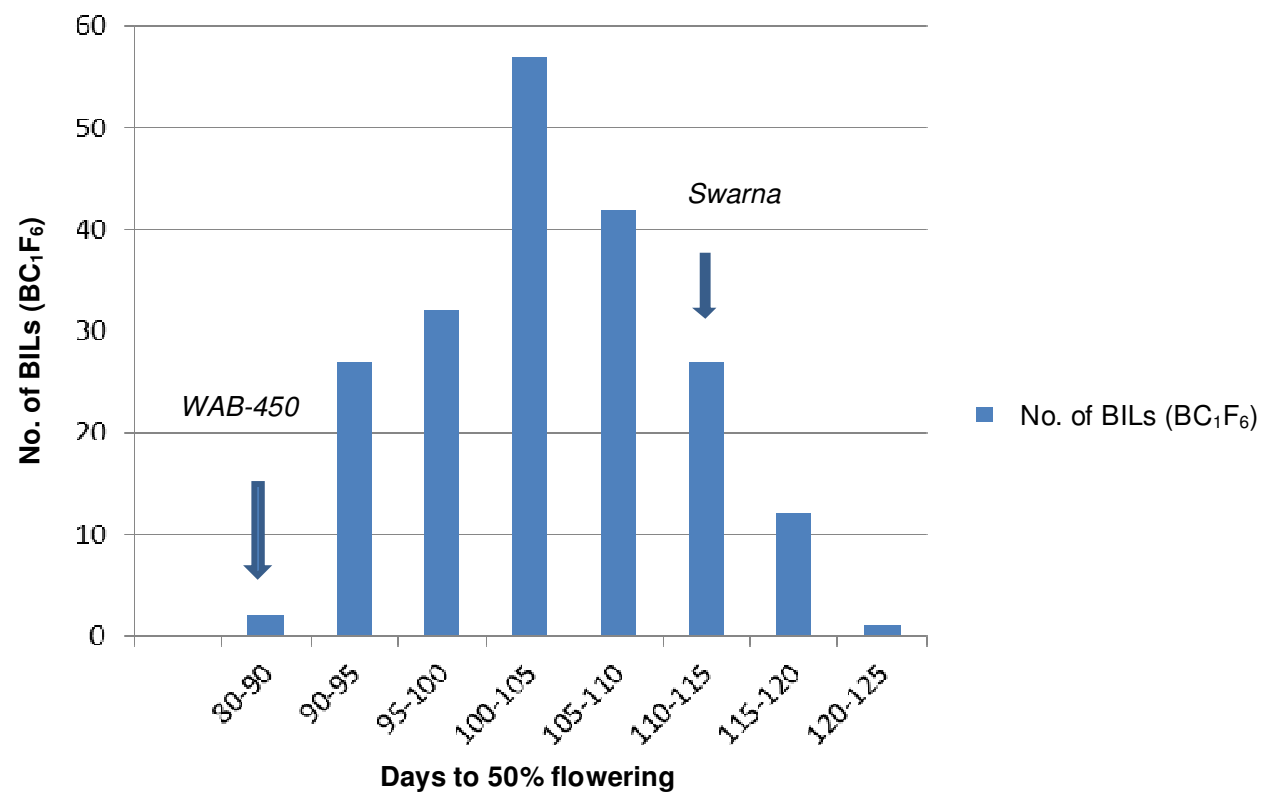

Figure 1. Frequency distribution of BILs at $50 \%$ flowering.

of variability as a result of intra- and inter-allelic interaction. The expression of transgressive segregants in this study was found to be skewed toward Swarna more than WAB-450; this may be due to larger genome contribution from Swarna which was used as the recurrent parent in the backcross programme. We can deduce from here that inter varietal crosses of WAB-450 used as donor on Swarna background will result in recombinants with more of Swarna genome.

Percentage superiority over donor and recurrent parent in earliness to maturity and productivity under rainfed upland condition indicated that a number of BILS performed better than the two parents (Table 2). Some BILs were found to have superiority of 11.4 to $18.8 \%$ above
Swarna and 5.4 to $30.7 \%$ above $W A B-450$. This may be due to expression of favorable alleles coming from the two parents; interaction between alleles or with the environment can result in better expression of trait in segregating population.

\section{Conclusion}

In this study, $W A B-450$ contributed alleles for earliness in flowering and maturity. A number of promising BILs were identified based on productivity under rainfed upland condition and mature in 122 to 133 days (at least 8 to 10 days early). Top performing BILs namely BIL-149, BIL- 
Table 2. Promising BILs derived from a cross between Swarna and WAB-450 for earliness and yield under rainfed upland condition.

\begin{tabular}{|c|c|c|c|c|c|c|c|c|c|c|c|c|c|}
\hline \multirow[b]{2}{*}{ No. of BIL } & \multirow{2}{*}{$\begin{array}{l}\text { Days to } 50 \% \\
\text { flowering }\end{array}$} & \multirow[b]{2}{*}{$\begin{array}{l}\text { Days to } \\
\text { Maturity }\end{array}$} & \multirow{2}{*}{$\begin{array}{l}\text { Plant } \\
\text { height } \\
(\mathrm{cm})\end{array}$} & \multirow[b]{2}{*}{$\begin{array}{c}\text { No. of } \\
\text { panicle/plant }\end{array}$} & \multirow{2}{*}{$\begin{array}{l}\text { Panicle } \\
\text { length } \\
(\mathrm{cm})\end{array}$} & \multirow{2}{*}{$\begin{array}{c}\text { Panicle } \\
\text { weight } \\
\text { (g) }\end{array}$} & \multirow[b]{2}{*}{$\begin{array}{l}\text { No. of grains/ } \\
\text { panicle }\end{array}$} & \multirow{2}{*}{$\begin{array}{c}\text { Spikelet } \\
\text { fertility } \\
(\%)\end{array}$} & \multirow[b]{2}{*}{$\begin{array}{l}\text { Test grain } \\
\text { weight }\end{array}$} & \multirow{2}{*}{$\begin{array}{c}\text { Harvest } \\
\text { index } \\
(\%)\end{array}$} & \multirow{2}{*}{$\begin{array}{l}\text { Grain yield } \\
(\mathrm{kg} / \mathrm{ha})\end{array}$} & \multicolumn{2}{|c|}{$\%$ superiority over } \\
\hline & & & & & & & & & & & & $\begin{array}{c}\text { Swarna } \\
\text { (Recurrent parent) }\end{array}$ & $\begin{array}{c}\text { WAB-450 } \\
\text { (donor) }\end{array}$ \\
\hline 149 & 95.5 & 127.0 & 79.0 & 13.1 & 19.0 & 2.7 & 124.0 & 93.2 & 24.2 & 43.5 & 6904 & 18.8 & 30.7 \\
\hline 188 & 108.5 & 130.0 & 86.4 & 11.3 & 21.9 & 3.3 & 127.1 & 79.5 & 25.3 & 43.8 & 6885 & 18.4 & 30.3 \\
\hline 183 & 90.0 & 122.5 & 101.5 & 8.0 & 21.5 & 3.8 & 137.0 & 95.1 & 26.5 & 41.7 & 6848 & 17.8 & 29.6 \\
\hline 150 & 107.0 & 133.5 & 84.0 & 10.9 & 22.5 & 4.1 & 140.8 & 70.9 & 23.2 & 40.4 & 6773 & 16.5 & 28.2 \\
\hline 142 & 94.0 & 127.0 & 86.3 & 12.4 & 22.3 & 3.9 & 148.8 & 85.3 & 20.2 & 42.8 & 6624 & 13.9 & 25.4 \\
\hline 60 & 109.5 & 138.0 & 83.1 & 13.8 & 21.6 & 3.4 & 136.8 & 78.4 & 22.0 & 41.5 & 6540 & 12.5 & 23.8 \\
\hline 53 & 108.5 & 143.0 & 83.3 & 14.7 & 22.0 & 2.9 & 127.5 & 90.6 & 25.6 & 41.8 & 6494 & 11.7 & 22.9 \\
\hline 6 & 104.5 & 127.0 & 80.9 & 15.3 & 20.9 & 2.9 & 99.7 & 63.8 & 22.7 & 45.5 & 6475 & 11.4 & 22.6 \\
\hline 163 & 103.0 & 131.0 & 83.0 & 9.7 & 19.5 & 3.0 & 120.0 & 88.9 & 22.7 & 39.8 & 5823 & 0.2 & 10.2 \\
\hline 5 & 109.5 & 143.0 & 88.8 & 11.9 & 23.5 & 3.4 & 141.4 & 80.4 & 20.3 & 44.5 & 5627 & -3.2 & 6.5 \\
\hline 118 & 103.0 & 127.0 & 80.7 & 12.0 & 19.7 & 2.6 & 115.8 & 90.9 & 22.4 & 40.0 & 5567 & -4.2 & 5.4 \\
\hline 174 & 94.5 & 127.0 & 81.2 & 10.8 & 20.7 & 2.2 & 95.7 & 94.0 & 25.3 & 42.3 & 5105 & -12.2 & -3.4 \\
\hline \multicolumn{14}{|l|}{ Parents } \\
\hline Swarna & 112.0 & 141.5 & 86.5 & 15.0 & 23.5 & 3.4 & 174.9 & 87.6 & 20.0 & 40.7 & 5813 & & \\
\hline WAB-450 & 82.5 & 113.0 & 113.0 & 6.2 & 24.0 & 4.1 & 144.0 & 87.8 & 26.9 & 43.9 & 5283 & & \\
\hline Mean of BILs & 103.8 & 133.4 & 81.8 & 11.6 & 20.8 & 3.0 & 132.5 & 84.0 & 22.2 & 40.4 & 5165 & & \\
\hline $\mathrm{CD}(5 \%)$ & 7.3 & 7.0 & 6.3 & 2.2 & 2.2 & 1.0 & 45.3 & 9.8 & 3.2 & 6.4 & 1436 & & \\
\hline CV $(\%)$ & 4.0 & 3.0 & 4.0 & 10.0 & 5.0 & 16.0 & 17.0 & 6.0 & 7.0 & 8.0 & 18.0 & & \\
\hline
\end{tabular}

188, BIL-183 and BIL-150, BIL-142, BIL-60, BIL53 and BIL-6 (Table 2) were found to be superior to recurrent parent Swarna (greater by $11 \%$ ) and donor parent $W A B-450$ (greater by $22 \%$ ). These BILs which combined earliness and productivity could be evaluated in multi-location trials to assess the stability of these genotypes in target rainfed upland condition. These results clearly indicate the potentiality of $W A B-450$ to contribute its genes for early maturity as well as productivity traits.

\section{REFERENCES}

Africa Rice (2011). Nerica Passport Data. Africa Rice Centre, Cotonou, Benin.http://www. africarice.org/
publications/nerica-comp/Annexes_Low.pdf

Dingkuhn M, Jones MP, Johnson DE, Sow A (1998). Growth and yield potential of Oryza sativa and O. glaberrima upland rice cultivars and their interspecific progenies. Field Crops Res. 57:57-69.

Jones M, Dingkuhn M, Aluko GK, Semon M (1997) Interspecific Oryza sativa L. X O. glaberrima Steud. Progenies in upland rice improvement. Euphytica 94(2):237-246.

Koffi G (1980). Collection and conservation of existing rice species and varieties in Africa. Agronomie Tropicale 34:228 237.

Porteres R (1955). History of the first samples of Oryza glaberrima collected from Africa. Agronomie Tropicale Botanique Applique 2:535-537.

Somado EA, Guei RG, Keya SO (2008). NERICA: the New Rice for Africa - a Compendium. Africa Rice Center (WARDA)/FAO/SAA. 2008. pp. 12-13

Swain DK, Jagtap Sandip S (2010). Development of SPAD Values of Medium- and Long-duration Rice Variety for Site- specific nitrogen management. J. Agron. 9:38-44.

UAS, Dharwad (2009). Package of Practice for Rice: University of Agricultural Sciences, Dharwad.http://agropedia.iitk.ac.in/content/packagepractices-paddy-developed-uas-dharwad.

WARDA (2001). NERICA rice for life. West Africa Rice Development Association (WARDA/ADRAO), 01 B.P. 2551, Bouaké 01, Côte d'Ivoire. http://www.warda.cgiar.org/ 